in less than 14 days, but 8 of 14 thymectomized animals bearing thymus-containing diffusion chambers had shown rejection at this time. Similar results have been reported in a preliminary communication from another laboratory ${ }^{15}$.

Thus the neonatally thymectomized rat, like the mouse ${ }^{6,7}$, can be partially restored immunologically by thymus-containing diffusion chambers which do not allow the passage of whole cells. However, as in the mouse, this chamber has little influence on the depressed lymphocyte count, and the improvement in mortality, delayed hypersensitivity and homograft reaction is only partial. If anything, restoration is less complete than in the mouse, a fact which may be related to the disadvantage of the larger thymus of the larger animal in diffusion of metabolites and its consequently more limited viability ${ }^{16}$. However, it appears that a humoral mechanism is involved. It remains uncertain whether the incompleteness of restoration of immunological function reflects the inefficiency of the thymus-containing chambers, or implies a second (cellular) mechanism of thymic action.

This work was supported by U.S. Public Health Service grant $C A-07179$ from the National Cancer Institute. Alan C. Aisenberg Barbara WiLKES

Huntington Memorial Hospital of Harvard University,

Massachusetts General Hospital, Boston.

${ }^{1}$ Miller, J. F. A. P., Proc. Roy. Soc., B, 156, 415 (1962).

Waksman, B. H., Arnason, B. G., and Jankovic, B. D., J. Exp. Med., 116, 187 (1962).

${ }^{3}$ Good, R. A., Dalmasso, A. P., Martinez, C., Areher, O. K., Pierce, J. C.,

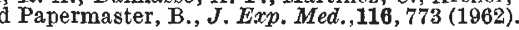

4 Miller, J. F. A. P., Lancet, i, 43 (1963).

${ }^{5}$ Dalmasso, A. P., Martinez, C., Sjodin, K., and Good, R. A., J. Exp. Med. 118, 1089 (1963).

'Levey, R. H., Trainin, N., and Law, L. W., J. Nat. Cancer Institute, 31, 199 (1963)

${ }^{7}$ Osaba, D., and Miller, J. F. A. P., J. Exp. Med.,119, 177 (1964).

${ }^{s}$ Aisenberg, A. C., Wilkes, B., and Waksman, B. H., J. Exp. Med., 116 759 (1962).

'Dvorak, H. F., and Waksman, B. H., J. Exp. Med., 116, 1 (1962).

${ }^{10}$ Jankovic, B. D., Waksman, B. H., and Arnason, B. G., J. Exp. Med., 116 159 (1962)

${ }^{1}$ Billingham, R. E., in Transplantation of Tissues and Cells, edit. by Billingham, R. E., and Silvers, W. K., 1 (Philadelphia, Wistar Institute Press, 1961).

12 Parrott, D. M. V., and East, J., Nature, 195, 347 (1962).

${ }^{13}$ East, J., Parrott, D. M. V., Chesterman, F. C., and Pomerance, A., J. Exp, (1963)

14 Pappenheimer, A. M., J. Exp. Med., 25, 477 (1914).

${ }_{15}$ MacGillivrey, M. N., Jones, V. E., and Leskowitz, S., Fed. Proc.,23, 189 (1964).

${ }^{16}$ Umbreit, W. W., Burris, R. H., and Stauffer, J. F., Manometric Techniques, third ed., 135 (Minneapolis, Burgess Publishing Co., 1957)

\section{Correlation between Complement-fixing Cell Antibody and Immunofluorescent Nuclear Antibody in Hamsters bearing 'SV40'-induced Tumours}

THE fact that transformation of hamster cells by ' $S V 40$ ' results in the synthesis of new viral-induced antigen(s) was first inferred by in vivo immunity tests ${ }^{1-4}$. This phenomenon was later detected in vitro by complementfixation $^{5}$ and by immunofluorescence $e^{6,7}$. This latter approach has characterized the antigen as being particu. late, intranuclear and present in 100 per cent of the transformed cells. Corresponding information regarding the intracellular site of the complement-fixing antigen and the proportion of cells in a culture synthesizing it has not yet been reported, and, indeed, such data are difficult to obtain by a direct approach.

Experiments were performed using both the complement-fixation and immunofluorescent techniques in order to correlate the two types of reactions. The sera tested were from tumour-bearing hamsters bled about three months after inoculation with 'SV40'-transformed cells.
Serum dilutions of $1: 2$ were used in the immunofluorescence assays and $1: 10$ in the complement-fixation tests. Control sera were obtained from hamsters with tumours induced by the hamster cell line ' $B H K 21$ ' (ref. 8), which was shown to be free of ' $S V 40$ '-tumour cell antigen'. Two sources of complement-fixing antigen were used: extracts of ' $H-50$ ' and ' $2 X-10$ ' cells. The first is a stable virusfree cell line derived from an ' $S V 40$ '-induced hamster tumour $^{10}$ and has afterwards undergone 40 passages; the second is also a stable virus-free cell line but derived from hamster cells transformed in vitro ${ }^{\mathbf{1 0}}$. Two full units of complement were used, in a semi-micro method to be described. For the immunofluorescence tests the same cell lines were used. They were grown as monolayers on round, $15-\mathrm{mm}$ coverslips and stained with the sera under test as described ${ }^{11}$. Known positive and negative sera were included in each run.

Table 1. COMPARISON OF RESCLTS OBTAINED BY COMPLEMENT-FIXATION AND IMMUNOFLURISANCENCE ON SERA FROM TUMOUR-BEARING HAMSTERS AND IMMUNOFLUORESCENCE ON SERA FROM TUMOU

\begin{tabular}{lrccc} 
Immuno- & \multicolumn{3}{c}{ Complement fixation } & \\
fluorescence & Positive & Questionable & Negative & Totals \\
Positive & 21 & 1 & 2 & 24 \\
Questionable & 1 & & 2 & 3 \\
Negative & 2 & 1 & $28^{*}$ & 31 \\
$\quad$ Totals & 24 & 2 & 32 & 58
\end{tabular}

Negative ith small * With few exceptions, tumours $(<10 \times 10 \mathrm{~mm})$

Similar results were obtained in both complementfixation and immunofluorescence tests with both hamster cell lines. The results of these paired experiments are summarized in Table 1 . Of 58 different sera tested, 5 gave questionable reactions in one or the other test. Of the 53 sera yielding clear-cut results in both tests, 49 (93 per cent) gave either positive or negative results both in the complement-fixation and in the immunofluorescence tests. Of these, 21 were positive in both tests and 28 were negative in both tests. The ' $B H K 21$ ' control sera were uniformly negative against the ' $S V 40$ ' cell antigens.

From the high degree of correlation between the com. plement-fixation and immunofluorescence results, both antibodies must develop simultaneously in hamsters carrying the ' $S V 40$ ' tumours, or the two different methods are detecting the same antibody. If this is true, then the complement-fixing antibody would be the result of the animal's immune response to the particulate, intranuclear, viral-induced antigen present in all virus-free transformed cells. Furthermore, if the antigens detect. able by complement-fixation and immunofluorescence elicit the same antibody, then the intracellular site of synthesis of the complement-fixing antigen would also be the nucleus, and the antigen would be produced in every cell of a transformed culture.

This investigation was supported by U.S. Public Health Service research grant $C A-04600$ from the National Cancer Institute, and $5 T I-A I 74$ and $A I 05382$ from the National Institute of Allergy and Infectious Diseases, National Institutes of Health.

Tsunehiro Kitahara

JANET S. BUTEL

Fred RapP

Joseph L. MELNICK

Department of Virology and Epidemiology,

Baylor University College of Medicine, Houston, Texas.

1 Khera, K. S., Ashkenazi, A., Rapp, F., and Melnick, J. L., J. Immunot., 91 604 (1963).

2 Habel, K., and Eddy, B. E., Proc. Soc. Exp. Biol. and Med.,113, 1 (1963).

- Koch, M. A., and Sabin, A. B., Proc. Soc. Exp. Biol. and Med.,113, 4 (1963)

4 Defendi, V., Proc. Soc. Exp. Biol. and Med.,113, 12 (1963)

5 Black, P. H., Rowe, W. P., Turner, H. C., and Huebner, R. J., Proc, U.S. Nat. A cad. Sci., 50, 1148 (1963).

' Rapp, F., Butel, J. S., and Melnick, J. L., Proc. Soc. Exp. Biol. and Med., 116, 1131 (1964)

7 Pope, J. H., and Rowe, W. P., J. Exp. Med., 120, 121 (1964).

B MacPherson, I., and Stoker, M., Virology, 16, 147 (1962).

'Rapp, F., Khera, K. S., and Melnick, J. L., Nature, 201, 1349 (1964).

${ }^{10}$ Ashkenazi, A., and Melnick, J. L., J. Nat. Cancer Inst., 30, 1227 (1963)

Rapp, F., J. Immunol., 88, 732 (1962). 